\title{
HUMAN RESOURCES AVAILABILITY IN GLAM DEVELOPMENT AT INDONESIAN INSTITUTE OF SCIENCES (LIPI)
}

\author{
Kamaludin* \\ Centre for Scientific Data and Documentation (PDDI)-Indonesian Institute of Sciences (LIPI), \\ Bandung \\ *Correspondence: kamaludin1961@gmail.com
}

\begin{abstract}
The collections of galleries, libraries, archives and museums (GLAM) are still scattered in the work units at LIPI. To manage these collections, adequate human resources, both quantitative and qualitative, are needed. When this research was conducted, there was a socialization activity to collaborate the GLAM management among work units at LIPI. This study aims to determine human resources available in developing GLAM at LIPI. The research method used was qualitative research. Analysis of data in qualitative research was carried out narratively. The research results show that human resources for gallery/museum exhibition at LIPI have been managed by the Center for the Utilization and Innovation of Science and Technology (PPII)-LIPI in collaboration with third parties since 2020. There were 49 librarians (37 expert librarians and 12 skilled librarians), while the number of archivists was 141 (one hundred and forty-one) people (83 Expert Archivists and 58 Skilled Archivists). The collaboration of PPII-LIPI with third parties has carried out human resources for museum management at LIPI since 2020. To improve the quality, human resources managing GLAM at LIPI need to be continuously improved, both through formal and non-formal education. The number of librarians and archivists are sufficient, but they must improve their abilities, considering that the GLAM institution at LIPI will just be developed. Of course, this GLAM is still perceived as a new institution by librarians and archivists at LIPI. It is recommended that during the development of the GLAM, gallery and museum management can be carried out by LIPI employees who have competence in galleries and museums.
\end{abstract}

\begin{abstract}
Koleksi galeri, perpustakaan, arsip dan museum (GLAM) saat ini masih tersebar di unit-unit kerja di LIPI. Untuk mengelola koleksi tersebut diperlukan sumber daya manusia yang memadai, baik kuantitatif maupun kualitatif. Pada saat penelitian ini dilakukan, ada kegiatan sosialisasi untuk mengkolaborasikan pengelolaan GLAM antar unit kerja di LIPI. Penelitian ini bertujuan untuk mengetahui sumber daya manusia yang tersedia dalam mengembangkan GLAM di LIPI. Metode penelitian yang digunakan adalah penelitian kualitatif. Analisis data dalam penelitian kualitatif dilakukan secara naratif. Dari hasil penelitian diketahui sumber daya manusia untuk pameran galeri/museum di LIPI telah dikelola oleh Pusat Pemanfaatan dan Inovasi Ilmu Pengetahun dan Teknologi (PPII)-LIPI bekerjasama dengan pihak ketiga sejak tahun 2020. Pustakawan sebanyak 49 orang (37 pustakawan ahli dan 12 pustakawan terampil), sedangkan jumlah arsiparis sebanyak 141 (seratus empat puluh satu) orang, (83 Arsiparis Ahli dan 58 Arsiparis Terampil). Sumber daya manusia pengelola museum di LIPI sejak tahun 2020 dilakukan oleh PPII-LIPI bekerjasama dengan pihak ketiga. Untuk meningkatkan kualitas, SDM pengelola GLAM di LIPI perlu terus ditingkatkan, baik melalui jalur pendidikan formal maupun nonformal. Jumlah pustakawan dan arsiparis sudah cukup, namun harus ditingkatkan kemampuannya, mengingat lembaga GLAM di LIPI baru akan dikembangkan, tentunya GLAM ini masih dipersepsikan sebagai lembaga baru oleh pustakawan dan arsiparis di LIPI. Disarankan dalam pengembangan GLAM, pengelolaan galeri dan museum dapat dilakukan oleh pegawai LIPI yang memiliki kompetensi di bidang galeri dan museum.
\end{abstract}

Keywords: Galleries, libraries, archives and museums (GLAM); Human resources; LIPI

\section{INTRODUCTION}

The term GLAM (Galleries, Libraries, Archives, Museums) is a term that is not yet popular enough for the general public. The term GLAM covers various cultural establishments that aim to provide access to knowledge for the general public. So, briefly, GLAM institutions can also 
be paired with cultural institutions for general understanding. From the four major categories of cultural institutions, there are two of the most well-known institutions in Indonesia, namely libraries and museums. On the other hand, data regarding the exact number of galleries, archival institutions and institutions that are still within the scope of GLAM cannot be found, and this may be because, in the general view, archival institutions are often overlapped with library functions, galleries are often equated with museums. Another unique case is that one agency manages almost everything that resembles the GLAM function (Rebin 2021).

GLAM refers to a cultural institution with access to knowledge as its mission (Constantine, Garrity, and Hammes 2018). Meanwhile, Farneth said that GLAM was an acronym used by the open-access community (Farneth 2016). GLAM often deals with high-value digital art reproductions. In this domain, artefacts must be protected, both actively and passively. He further mentioned that GLAM Agencies might have their collections of images that carry 'privacy sensitive' information, such as photographic material from identifiable individuals (Temmermans et al. 2017).

The Australian Center for Broadband Innovation (ACBI) mentions that GLAM is a term used in Australia to describe various public interest organizations that collect and display cultural and environmental materials. In Europe and North America, the term LAM (Library, Archive and Museum) is used to describe this sector, including galleries as part of museums (ACBI 2014).

GLAM is a collective memory of a nation and can be used as a cultural heritage. The availability of books in the Library, photos in the Gallery, the Archives at the Archives Institution, also sites in the Museum can tell stories about history that future generations will not know. In plain view, GLAM has different collections. If it is studied more carefully, the collections at GLAM institutions are sustainable. Institutions, such as GLAM, can be combined to make it easier for users to know their cultural heritage (Fitrina and Lasenta 2017). All GLAM institutions have the same primary mission, namely protecting society's cultural and scientific heritage through acquiring, managing, preserving, and presenting materials of any kind. However, there are differences from one institution to another, for example, the differences in special missions (Constantine, Garrity, and Hammes 2018).

Under the traditional model, GLAM institutions function as gatekeepers in redeeming cultural knowledge and practices. This transmission usually occurs through a one-way information channel leading from the institution to the audience. However, recently, the role of museums and libraries in our society and on university campuses has changed as technology changes the way people access and use information. While museums and libraries still play an indispensable role in helping individuals find information, the evolution of technology has pulled such institutions further and further into continuous expansion. The openness and inclusiveness of these infosphere fundamentals give GLAM institutions an unprecedented opportunity to reach new users while at the same time giving those users an unprecedented opportunity to exert influence on this previously authoritative institution (Constantine, Garrity, and Hammes 2018).

To manage GLAM institutions, reliable human resources who understand GLAM are needed. Human resources are ordinary workers or employees, but their expertise and intellectual property can become institutions' strategic partners. In this case, equating human resource management strategies parallel with business strategies is essential and the main thing to help companies execute business strategies. The skills possessed by human resources are needed in strategic partners in the areas of databases, decision making and other fields (Tiyanto 2012).

The human resources department is responsible for helping managers to be good trainers and advisors to their subordinates. Creating effective training and development programs for both new (orientation) and existing employees (skills development) involved in the training and development program are needed, so does planning the company's need for training and 
development programs, and evaluating the effectiveness of training and development programs (Husaini 2017). Often institutions that want to be innovative and provide unconventional services or expand on traditional thinking find it impossible to attract formally qualified staff (Shipp 2016).

The Indonesian Institute of Sciences in this Institutional Regulation, abbreviated as LIPI, is a Non-Ministerial Government Institution under and responsible to the President through the Minister who carries out government affairs in science and technology. LIPI has the task of carrying out government duties in scientific research under the provisions of the legislation. Based on the organizational structure, there are 37 work units in the Indonesian Institute of Sciences, from the Chairman of LIPI to the smallest work unit (LIPI 2020). Hence, the potential of human resources and collections related to GLAM is big enough.

From the description mentioned above, the research question posed is how the human resources available in developing Galleries, Libraries, Archives, and Museums (GLAM) at the Indonesian Institute of Sciences (LIPI).

\section{METHOD}

The research method used is qualitative research. In qualitative research, the main characteristics come from the natural/reality background in the community. The stages carried out are observation, interviews, and document review. The presentation and analysis of data in qualitative research are carried out narratively. Furthermore, Subandi stated that in carrying out data collection techniques, it could be done through: a. Observation, namely observing the object of research. Observation can be done in two ways: first, direct observation and indirect observation. In direct observation, the researcher observes the research's object directly. In an indirect observation, observations can be made through recordings at the time of research or use past recordings stored as library collections (i.e. a collection of books and/or non-books). b. Interviews, to further clarify data collection carried out by interviews and conducted on several informants and resource persons to obtain data (Subandi 2011).

Data resources in this study were obtained from the Bureau for Organization and Human Resources (BOSDM)-LIPI and the Research Center for Biology-LIPI. Data were collected from the document: Museum Zoologicum Bogoriense/Bogor-Zoological Museum published by Zoology Division "Museum Zoologicum Bogoriense" Research Center for Biology-LIPI, 2018, observations and in-depth interviews were conducted using question and answer directly to the Bureau for Organization and Human Resources-LIPI staff, the Research Center for Biology-LIPI researcher, librarian, and archivist at LIPI Bandung on July 2021.

When this research was carried out, the development of GLAM at the Indonesian Institute of Sciences was in the socialization stage to related work units to equalize perceptions about collaboration in GLAM development.

\section{RESULTS AND DISCUSSION}

Human resource management is a process of dealing with various problems in the scope of employees, labourers, managers and other workers to support the activities of the organization or company to achieve predetermined goals. The Managers must ensure that the company or an organization has the right workforce at the right place and at the right time, who can complete tasks that will help the company achieve its overall goals effectively and efficiently. To achieve this goal, the study of personnel management will show how companies should get, develop, use, evaluate, and maintain the correct number (quantity) and type (quality) of employees. Human resource management discusses the great potential of human labour, which is the driving force behind the supporting factors of management activities that must be utilized as much as possible 
through synergy with the environment. Undeniably, technological changes are fast, forcing organizations to adapt to their business environment (Husaini 2017).

In the discussion of human resource management managing Galleries, Libraries, Archives, Museums (GLAM) at the Indonesian Institute of Sciences (LIPI), the authors divide 4 (four) groups of human resources, namely: human resources for managing galleries, human resources for managing libraries, human resources for managing archives, and human resources for managing museums.

\subsection{Human resources for managing galleries}

The art gallery exhibition area is a place to display artists' ideas to visitors through the visual quality of the display of artworks (Hanif et al. 2013). In the museum, there are showrooms which can also be called galleries. Art galleries have a goal in preserving art with a focus, especially on artists and art connoisseurs. Management of museums and galleries in the preparation of art collections, whether in paintings, artwork, installations, and others, is very important in a showroom. Furthermore, Yendra said that the construction of art galleries made by individuals or the private sector has a cooperative relationship with certain parties because the established art galleries must have a sound management system. With the basis of a management system that is careful and sensitive to changes and market demands, there will be many benefits to be gained from art galleries (Yendra 2018).

The management of the exhibition museum until 2019, such as the management of the Zoologicum Bogoriense Museum Exhibition under the Research Center for Biology-LIPI, unified wholly with the Zoologicum Bogoriense Museum/Museum Zoologicum Bogoriense (MZB) at Cibinong as a "factory of knowledge". Since 2020, the management of the Museum Exhibition has been managed by the Center for the Utilization and Innovation of Science and Technology (PPII)-LIPI with third parties. In terms of Collection and Curatorial, since 2021, collection management has become the responsibility of PPII-LIPI by appointing one collection manager (Rahmadi 2021).

As an exhibition unit, Museum Zoologicum Bogoriense (MZB) is a part of the Indonesian Institute of Sciences' community services to introduce the knowledge of Indonesian fauna diversity to the public. It is showcasing 122 displays that constitute 954 Indonesia's animal species (LIPI 2018).

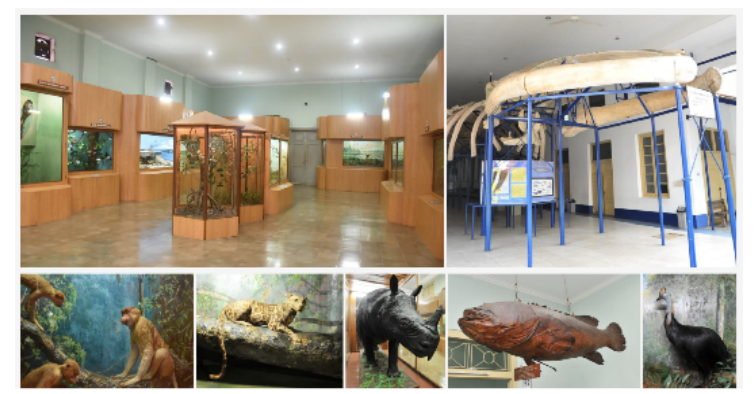

Figure 1. $M Z B$ Exhibition Room

(Source: Zoology Division "Museum Zoologicum Bogoriense” Research Center for BiologyIndonesian Institute of Sciences)

From the data above, it could be concluded that the human resources who work at the LIPI gallery must improve their knowledge to apply science and technology developments. They must understand the arts so that they can manage museum exhibitions. Howard mentioned that to identify information professionals who work in galleries, the search for gallery information 
professionals inevitably leads to resources about librarians who have an educational background in the arts (Howard 2015).

\subsection{Human resources for managing libraries}

Libraries manage collections of written works, printed works, and/or recorded works professionally with a standard system to meet the users' educational, research, preservation, information, and recreational needs. Library collections are all information in the form of written works, printed works, and/or recorded works in various media that have educational value, which is collected, processed, and served. The library aims to provide services to users, increase their love of reading, and broaden their horizons and knowledge to educate the nation's life. The library staff consists of librarians and library technical staff. Librarians must meet the qualifications according to the national library standards. The duties of the library technical staff can be concurrently by the librarian following the conditions of the library concerned (Indonesia 2007).

In the Functional level of Expert Librarians, there are 4 (four) levels, namely Main Expert Librarian (Pustakawan Ahli Utama); Associate Expert Librarian (Pustakawan Ahli Madya); Young Expert Librarian (Pustakawan Ahli Muda) and First Expert Librarian (Pustakawan Ahli Pertama) (MenpanRb 2014). The human resources for library management available at the Indonesian Institute of Sciences consist of Expert Librarians and Skilled Librarians. Expert Librarians based on data obtained from the Bureau for Organization and Human Resources (BOSDM)-LIPI consist of 3 (three) Main Expert Librarians, 9 (nine) Associate Expert Librarians, 17 (seventeen) Young Expert Librarians and 8 (eight) First Expert Librarians. The percentage composition of Expert Librarians can be seen in Figure 2 below.

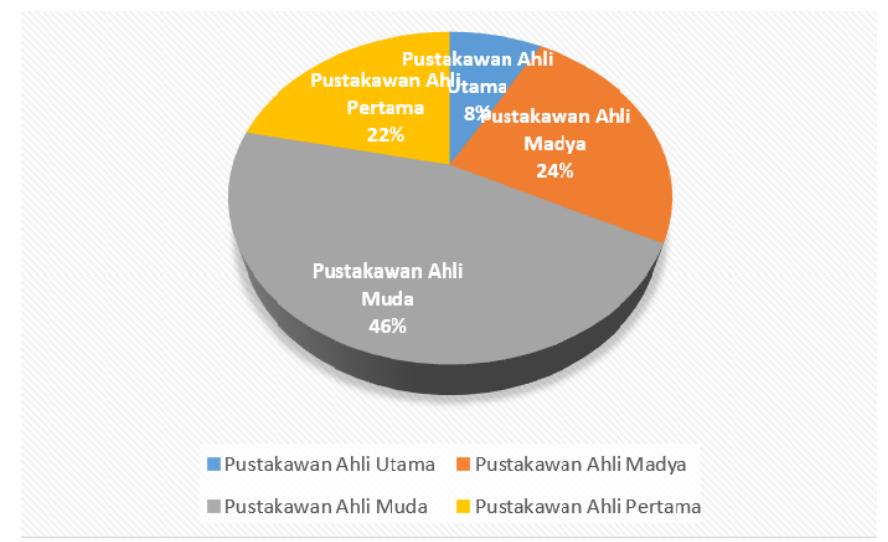

Figure 2. Composition of Expert Librarian

(Source: The Bureau of Organization and Human Resources-LIPI, 2021)

Meanwhile, the Skilled Librarian based on data obtained from the Bureau for Organization and Human Resources (BOSDM)-LIPI consists of 1 (one) Supervisory Librarian (Pustakawan Penyelia), 10 (ten) Proficient Librarians (Pustakawan Ahli Mahir) and 1 (one) Implementing Librarian (Pustakawan Terampil). The percentage composition of Skills Librarians can be seen in Figure 3 below. 


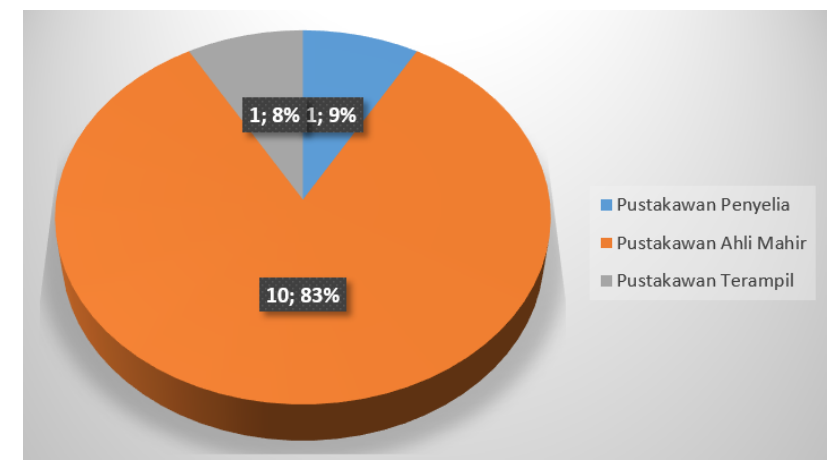

Figure 3. Composition of Skilled Librarian

(Source: The Bureau of Organization and Human Resources-LIPI, 2021)

In developing GLAM at LIPI, the number of librarians as many as 49 people (37 expert librarians and 12 skilled librarians) is sufficient. However, they must improve their abilities, considering that the GLAM institution at LIPI will just be developed. Of course, this GLAM is still perceived as a new institution by librarians at LIPI.

The development of human resources in this library group needs to be improved, especially at the ability level. Participation in education and training is very important. At the National Library of Indonesia, there are two types of librarianship education and training: functional training for expert librarians and functional training for skilled librarians (Supriyanto 2016).

The role of the librarian needs to be explored in alignment with the latest developments. In the early days of computing, a logging department was established to provide inventory control and support primary core data for managing objects. The databases created may result from an inventory, as they record only simple physical descriptions without information of history or significance. Then this activity is extended to record primary object data so that the data can be used in the long term as information (Koot 2001).

As knowledge managers, information professionals need to collect and promote information to different audiences, manage knowledge stores, facilitate the flow and dissemination of information, transform information into new products and/or new services (Vassilakaki, Giannakopoulos, and Triantafyllou 2019).

Information professionals must embrace a role also as a subject librarian in terms of serving as a link between historical information and data, between data, metadata and the discovery of meaningful interpretations and interconnections between concepts; develop new ways to present information derived from metadata and linkages with other resources to designated audiences and assist in copyright clearance of information used to fulfil this purpose (Vassilakaki, Giannakopoulos, and Triantafyllou 2019).

\subsection{Human resources for managing archives}

In the Regulation of the Minister for Empowerment of State Apparatus and Bureaucratic Reform of the Republic of Indonesia, number 13 the year 2016, concerning Amendments to the Regulation of the Minister of Empowerment of State Apparatus and Bureaucratic Reform number 48 the year 2014, concerning the Functional Position of Archives, it is stated that archives are recordings of activities or events in various forms and media, following the development of information and communication technology made and accepted by state institutions, regional governments, educational institutions, companies, political organizations, community organizations, and individuals in the implementation of social, national and state life. An archivist is a civil servant who has competence in the field of archives obtained through 
formal education and/or archival education and training and has the functions, duties, and responsibilities of carrying out archival activities appointed by authorized officials within state institutions, regional governments, village governments, and organizational units of state universities. Archivists consist of two categories: Expert Archivist and Skilled Archivist. Expert Archivists are those whose implementation of their functions, duties, and authority requires mastery of science and technology in the field of archives. Skilled Archivists are archivists with technical qualifications or professional support whose functions and duties and their authorities require mastery of technical knowledge in the field of archives (Indonesia Berita 2016).

Human resources for Archival management available at the Indonesian Institute of Sciences (LIPI) consist of Expert Archivists and Skilled Archivists. Expert Archivists (Arsiparis Ahli) based on data obtained from the Bureau for Organization and Human Resources (BOSDM)-LIPI consist of 0 (zero) Main Expert Archivists (Arsiparis Utama), 7 (seven) Associate Expert Archivists (Arsiparis Madya), 36 (thirty-six) Young Expert Archivists (Arsiparis Muda) and 40 First Expert Archivists (Arsiparis Pertama). The composition of the percentage of Expert Archives can be seen in Figure 4 below.

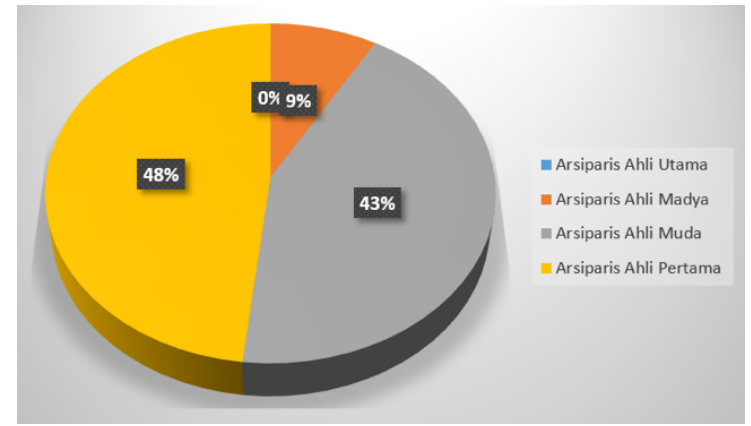

Figure 4. Composition of Expert Archivists

(Source: The Bureau of Organization and Human Resources-LIPI, 2021)

Moreover, the Skilled Archivists based on data obtained from the Bureau for Organization and Human Resources (BOSDM)-LIPI have consisted of 19 (nineteen) Supervisory Archivists (Arsiparis Penyelia), 23 (twenty-three) Proficient Archivist (Arsiparis Mahir), and 16 (sixteen) Implementing Archivists (Arsiparis Terampil). The composition of the percentage of Skilled Archivists can be seen in Figure 5 below.

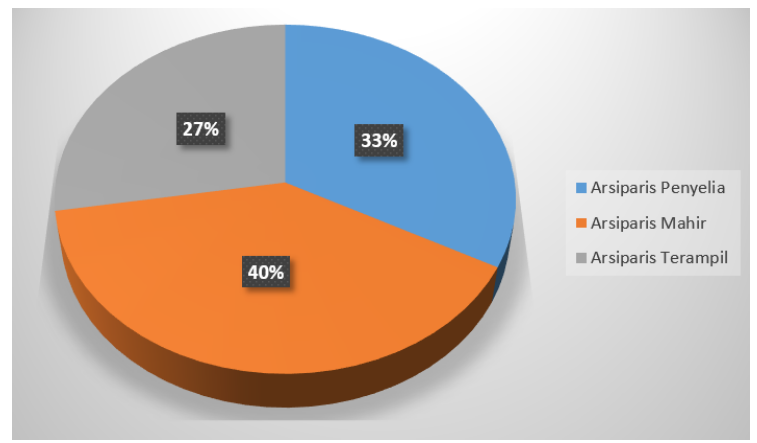

Figure 5. Composition of Skilled Archivists

(Source: The Bureau of Organization and Human Resources-LIPI, 2021)

In developing GLAM at LIPI, the number of archivists as many as 141 (one hundred and forty-one) people (83 Expert Archivists and 58 Skilled Archivists) is more than enough, but 
Archivists have to improve their abilities, considering that the GLAM institution at LIPI is a new institution.

Vassilakaki said that human resources development for archive managers need to be continuously improved, both through formal and informal education. In a time of rapid technological development in the information landscape, archivists must undertake a broad educational role. This transformation will also equip archivists to respond to the new challenges. In addition, the additional challenges posed by managing digital archives are born, dealing with budget constraints, obtaining and processing an increasing number of digital archives born are just a few factors that emphasize the important role of digital archivists. An increasingly important role is due to the development and use of institutional repositories to manage and disseminate digital archives (Vassilakaki and Moniarou-papaconstantinou 2017).

\subsection{Human resources for managing museums}

In the Government Regulation of the Republic of Indonesia, number 66, the year 2015, concerning Museums, it is stated that museums are institutions that function to protect, develop, utilize collections, and communicate them to the public. Museum collections consist of cultural conservation objects, cultural conservation buildings, and/or cultural conservation and/or noncultural conservation structures which constitute material evidence of cultural products and/or natural and environmental materials that have important values for history, science, education, religion, culture, technology, and/or tourism. Museum Managers are some people who run the activities of the Museum. Museum management is an integrated effort to protect, develop, and utilize collections through policy arrangements for planning, implementing, and supervising for the maximum welfare of the community. Museum utilization is the utilization of the collection for the most significant benefit of the community's welfare while maintaining its sustainability (Peraturan Pemerintah 2015).

As an exhibition unit, Museum Zoologicum Bogoriense (MZB) is part of the Indonesian Institute of Sciences (LIPI) community service to introduce the knowledge of the diversity of Indonesian fauna to the public. Displaying 122 displays representing 954 species of Indonesian animal scientific collections, in addition to the collections exhibited at Bogor. MZB also accommodates a large number of scientific collections. With a total collection of 2,792,611 specimens (as of the end of 2018). This collection increases every year, making it the museum with the most significant scientific collection in Southeast Asia (LIPI 2018). More detail can be seen in Figure 6 below.

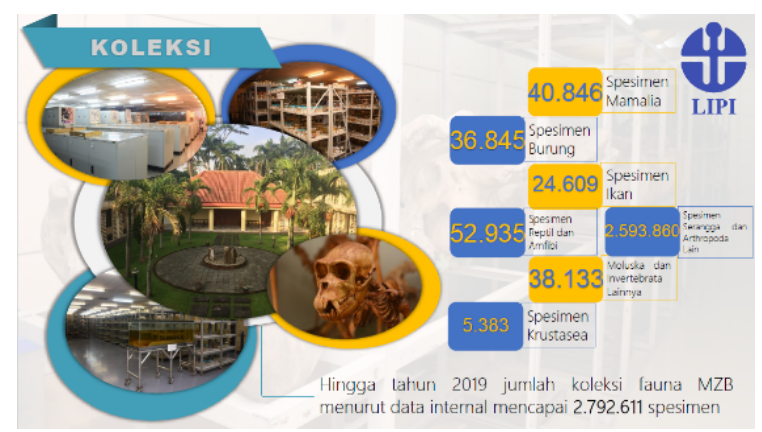

Figure 6. Scientific Collections "Museum Zoologicum Bogoriense"

(Source: Zoology Division "Museum Zoologicum Bogoriense" Research Center for BiologyIndonesian Institute of Sciences)

Since its founding in 1894, the museum has covered a more comprehensive range of research interests, including insects, fish, molluscs, amphibians, reptiles, birds and mammals. 
Since then, exploration and research on various aspects of Indonesia's fauna have continued (LIPI 2018). Since its establishment, the museum has been recognized with several different affiliations and names. More details can be seen in Figure 7 below.

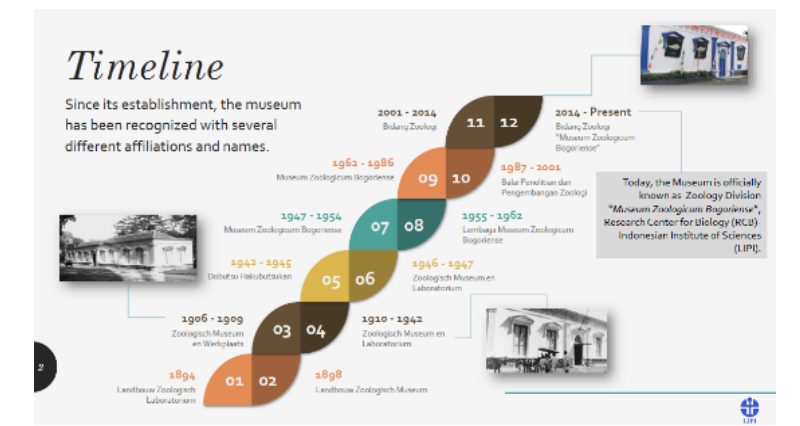

Figure 7. Timeline of several different affiliations and names

(Source: Zoology Division "Museum Zoologicum Bogoriense" Research Center for BiologyIndonesian Institute of Sciences)

From the data, it is known that since 2020, the management of the Museum Exhibition has been managed by the Center for the Utilization and Innovation of Science and Technology (PPII)-LIPI in collaboration with third parties (LIPI 2018).

For the management of this museum to be fully managed by LIPI, the development of human resources who manage the museum at LIPI, both quantity and quality, needs to be continuously improved.

Rebin mentioned that the classic problems and challenges of GLAM institutions in general and particularly museums are the low awareness and concern of the community, the lack of attention from local governments to museum management, the lack of museum educational institutions, inadequate quality and quantity of human resources, management systems that are still underdeveloped, a weak inter-agency cooperation network (Rebin 2021). Koot said that museum libraries must be more than warehouses that collect books, and their librarians must be more than custodians of book collections. In a museum setting, librarians have a job that suits them: they have the opportunity to take a leading role as information strategists and create a dynamic environment (Koot 2001).

\section{CONCLUSION}

Indonesian Institute of Sciences (LIPI) has an extensive collection of Galleries, Libraries, Archives, and Museums (GLAM), and from year to year, the GLAM collection will continue to increase in line with research activities carried out by LIPI. In order to manage the GLAM collection, adequate human resources are needed, both in terms of quantity and quality. The management of the GLAM collection has been carried out separately from the four institutions, namely gallery, library, archive and museum institutions; when GLAM is developed, collaboration and change in work culture are needed.

Several work units have carried out human resources for gallery management at LIPI. For example, the management of the Zoologicum Bogoriense Museum at Cibinong. The management of this gallery since 2020 has been carried out by the Center for the Utilization and Innovation of Science and Technology (PPII)-LIPI collaboration with third parties. It is recommended that when GLAM is established, the management of the gallery at LIPI will be entirely carried out by human resources from LIPI. 
Human resources for library management are carried out by LIPI librarians and LIPI Library Technical Staff. All librarians and technical staff of the LIPI library work in the Center for Scientific Data and Documentation (PDDI)-LIPI. LIPI libraries are located in several areas where LIPI offices are located, e.g. at LIPI Bali, Bandung, Bogor, Cibinong, Serpong and Jakarta. Librarians and library technical staff need to improve their knowledge and change the work culture to collaborate with three other institutions: gallery, archive, and museum.

Human resources for managing archives at LIPI are archivists, both expert and skilled archivists who work at LIPI. These archivists have attended both formal and non-formal education and training, but because archivists currently work in their institutions, it is necessary to change the work culture in the future so that collaboration at GLAM institutions will be easy.

Human resources for museum management at LIPI since 2020 have been carried out by the Center for the Utilization and Innovation of Science and Technology (PPII)-LIPI in collaboration with third parties. During the development of the GLAM, it is recommended that museum management be carried out by LIPI employees who have competence in museums.

Librarians, in general, earn master's degrees in library and information science, whereas those working in the museum field have diverse backgrounds (e.g. art history, science, history, anthropology), and the level of education depends on the type of institution and the position in which it is held. Likewise, archivists may also have diverse educational routes (e.g. history or library science, with or without additional archive certification). Graduate programs in museum studies, archives and records management, and library and information science offer professional training and/or certification designed to develop and enhance skills (Allen 2017).

The development of these skills will further assist information professionals in taking part in large-scale, international cultural heritage projects and, most importantly, working closely and collaboratively with researchers from other disciplines. It will also enable them to communicate equally and share a common language with an interdisciplinary research team (Vassilakaki, Giannakopoulos, and Triantafyllou 2019).

\section{BIBLIOGRAPHY}

ACBI, CSIRO. 2014. "Innovation Study: Challenges and Opportunities for Australia's Galleries, Libraries, Archives and Museums."

Allen, Stephanie; et al. 2017. "Collective Wisdom: An Exploration of Library, Archives and Museum Cultures." Published on Behalf of the Coalition to Advance Learning in Archives, Libraries and Museums by OCLC.

Constantine, Elizabeth, Jane Garrity, and Megan Hammes. 2018. "Libraries and Museums : Fostering GLAM Collaboration at the University of Iowa." The University of Iowa Libraries Administrative and Public Relations Materials. https://doi.org/DOI: https://doi.org/10.17077/yc01-mco1.

Farneth, David. 2016. "How Can We Achieve GLAM? Understanding and Overcoming the Challenges to Integrating Metadata across Museums, Archives, and Libraries: Part 2 Museums , Archives , and Libraries : Part 2." Cataloging \& Classification Quarterly 54 (5-6): 292-304. https://doi.org/10.1080/01639374.2016.1192078.

Fitrina, Dwi, and C Lasenta. 2017. "Galery, Library, Archive, and Museum (GLAM) Sebagai Upaya Transfer Informasi Dwi." Shaut Al-Maktabah Jurnal Perpustakaan, Arsip Dan Dokumentasi 8 (2): 143-53. https://doi.org/0.15548/shaut.v9i2.113.

Hanif, Mohamad, Abdul Wahab, Alia Fatin, and Ahmad Zuhardi. 2013. "Human Visual Quality: Art Gallery Exhibition." Procedia - Social and Behavioral Sciences 101: 476-487. https://doi.org/10.1016/j.sbspro.2013.07.221.

Howard, Katherine. 2015. "Educating Cultural Heritage Information Professionals for Australia' s Galleries , Libraries , Archives and Museums: A Grounded Delphi Study." Thesis Submitted in 
Fulfilment of Therequirements for the Degree of Doctor of Philosophy.

Husaini, Abdullah. 2017. "Peranan Manajemen Sumber Daya Manusia Dalam Organisasi." Jurnal Warta, no. 51.

Indonesia berita. 2016. Peraturan Menteri Pendayagunaan Aparatur Negara Dan Reformasi Birokrasi Republik Indonesia, Nomor 13 Tahun 2016, Tentang Perubahan Atas Peraturan Menteri Pendayagunaan Aparatur Negara Dan Reformasi Birokrasi Nomor 48 Tahun 2014, Tentang Jabatan Fungsional.

Indonesia, Presiden. 2007. Undang-Undang Republik Indonesia, Nomor 43 Tahun 2007, Tentang Perpustakaan.

Koot, Geert-Jan. 2001. "Museum Librarians as Information Strategists." INSPEL 87 (July 2000): $248-58$.

LIPI. 2020. Peraturan Lembaga Ilmu Pengetahuan Indonesia Republik Indonesia, Nomor 24 Tahun 2020, Tentang Organisasi Dan Tata Kerja Lembaga Ilmu Pengetahuan Indonesia.

LIPI, Zoology Division "Museum Zoologicum Bogoriense" Research Center for Biology-Indonesian Institute of Sciences. 2018. "Museum Zoologicum Bogoriense." Profil Museum Zoologicum Bogoriense, 2018.

MenpanRb. 2014. Peraturan Menteri Pendayagunaan Aparatur Negara Dan Reformasi Birokrasi RI, No. 9 Tahun 2014, Tentang Jabatan Fungsional Pustakawan Dan Angka Kreditnya.

Peraturan Pemerintah, Indonesia. 2015. Peraturan Pemerintah Republik Indonesia Nomor 66 Tahun 2015 Tentang Museum.

Rahmadi, Cahyo. 2021. "Museum Zoologicum Bogoriense Dan Perannya Dalam Scientific GLAM." FGD GLAM PDDI LIPI.

Rebin, Biyanto. 2021. "GLAM Di Indonesia: Urgensi Gerakan Akses Terbuka Instansi GLAM Di Indonesia OpenGLAM Dan Data Terbuka." FGD GLAM PDDI LIPI.

Shipp, John Neville. 2016. "Do I Really Need Specialist Qualifications to Work as a Professional in a Gallery , Library , Archive or Museum ?" The Australian Library Journal 65 (4): 280-287. https://doi.org/10.1080/00049670.2016.1233604.

Subandi. 2011. "Qualitative Description as One Method in Performing Arts Study." Harmonia 11 (2): $173-179$.

Supriyanto. 2016. "Profesionalisme Tenaga Pengajar DIKLAT Kepustakawanan." Madika 2 (1).

Temmermans, Frederik, Touradj Ebrahimi, Siegfried Foessel, Jaime Delgado, Takaaki Ishikawa, Ambarish Natu, and Peter Schelkens. 2017. "Open Access JPEG Privacy and Security Framework for Social Networking and GLAM Services." EURASIP Journal on Image and Video Processing 68: 1-9. https://doi.org/10.1186/s13640-017-0216-z.

Tiyanto, Prihatin. 2012. "Peran Strategi SDM Dalam Membangun Organisasi Bersaing." CEBAM FE UNISSULA 1 (1).

Vassilakaki, Evgenia, Georgios Giannakopoulos, and Ioannis Triantafyllou. 2019. "The Role of Libraries in Managing Cultural Heritage Information." International Conference on "Future of Libraries," no. April.

Vassilakaki, Evgenia, and Valentini Moniarou-papaconstantinou. 2017. "Beyond Preservation: Investigating the Roles of Archivist Article Information:" Library Review 66 (3): 110-126. https://doi.org/10.1108/LR-09-2016-0077.

Yendra, Sasferi. 2018. "Museum Dan Galeri.” Jurnal Tata Kelola Seni 4 (2): 103-108. 